Mateusz Marek Polaczek ${ }^{1,}{ }^{2}$, Jacek Zych', Karina Oniszh ${ }^{3}$, Janusz Szopiński', Jacek Grudny', Kazimierz Roszkowski-Śliż ${ }^{1}$

'III Klinika Chorób Płuc, Instytut Gruźlicy i Chorób Płuc

Kierownik: prof. dr hab. K. Roszkowski-Śliż

${ }^{2}$ Zakład Anatomii Prawidłowej i Klinicznej Centrum Biostruktury Warszawskiego Uniwersytetu Medycznego

Kierownik: prof. dr hab. B. Ciszek

${ }^{3}$ Zakład Radiologii i Diagnostyki Obrazowej im. dr Marii Werkenthin, Instytut Gruźlicy i Chorób Płuc

Kierownik: dr I. Bestry

\title{
Pneumocystozowe zapalenie płuc u zakażonych HIV przy wspótistniejącym zakażeniu cytomegalowirusem. Opis dwóch przypadków i przegląd literatury
}

\author{
Pneumocystis pneumonia in HIV-infected patients with cytomegalovirus co-infection. \\ Two case reports and a literature review \\ Praca nie była finansowana
}

\begin{abstract}
Pneumocystis pneumonia (PCP) is one of the infectious lung diseases diagnosed in HIV-infected patients. The pathogen responsible for the development of this opportunistic infection is an atypical fungus called Pneumocystis jiroveci. PCP remains the most common disorder diagnosed at the onset of acquired immunodeficiency syndrome (AIDS), especially in individuals not aware of their HIV infection. The most important risk factor of PCP development in HIV-infected person is the decrease of T CD4 ${ }^{+}$cell number below $200 / \mathrm{mcL}$. Clinical symptoms consist of: chronic cough, dyspnoea and weakness. Arterial blood gas analysis often reveals the presence of hypoxaemia, and high-resolution computed tomography imaging shows diffuse ground glass opacities. Treatment is based on intravenous administration of trimetoprim-sulfamethoxasole. In patients with moderate and severe symptoms of PCP it is recommended that corticosteroids are used. Co-infection with cytomegalovirus (CMV) is a poor prognostic sign in PCP. CMV-related organ disease should be suspected in patients with T CD4 ${ }^{+}$cell number lower than $50 / \mathrm{mcL}$. It is arguable whether CMV infection in symptomatic PCP patients should be treated. There are suggestions that corticosteroids used in PCP patients with CMV co-infection could promote the development of CMV pneumonia. In the present paper we present two patients with PCP, unaware of their HIV infection. In both cases a CMV co-infection was found.
\end{abstract}

Key words: pneumocystis pneumonia, HIV-related opportunistic infections, PCP/CMV co-infection

Pneumonol. Alergol. Pol. 2014; 82: 458-466

\section{Streszczenie}

Pneumocystozowe zapalenie płuc (PCP) jest jedną z wielu infekcyjnych chorób układu oddechowego u zakażonych HIV wywoływaną przez patogen Pneumocystis jiroveci, zaliczany do grzybów. Pneumocystoza jest od ponad 30 lat najczęstszą chorobą wskaźnikową zespołu nabytego niedoboru odporności (AIDS). Najważniejszym czynnikiem ryzyka rozwoju PCP jest obniżenie liczby limfocytów T CD4+ poniżej 200 komórek/mcL. Objawy kliniczne choroby to: przewlekły kaszel, duszność i osłabienie. W badaniu gazometrycznym krwi tętniczej lub arterializowanej krwi kapilarnej często stwierdza się hipoksemię, a w tomografii komputerowej o wysokiej rozdzielczości — obraz matowej szyby. Leczeniem z wyboru jest parenteralne podawanie trimetoprimu z sulfametoksazolem, $\mathrm{U}$ chorych w średnim i ciężkim stanie zaleca się systemowe podawanie glikokortykosteroidów. Wspótistnienie zakażenia wirusem cytomegalii (CMV) pogarsza rokowanie chorych. Narządowego zajęcia w przebiegu zakażenia CMV należy poszukiwać u chorych z liczbą komórek

Adres do korespondencji: lek. Mateusz M. PolaczekIII Klinika Chorób Płuc, Instytut Gruźlicy i Chorób Płuc, ul. Płocka 26, 01-138 Warszawa, e-mail: polaczek@me.com

DOI: 10.5603/PiAP.2014.0060

Praca wpłynęła do Redakcji: 1.03.2014 r

Copyright (C) 2014 PTChP

ISSN 0867-7077 
T CD4 + poniżej 50/mcL. Kwestią sporną pozostaje leczenie zakażenia CMV u chorych z rozpoznanym PCP. Uważa się, że w większości przypadków zakażenie CMV pozostaje bezobjawowe. Glikokortykosteroidy podawane w przypadkach PCP o cięższym przebiegu mogą pogarszać rokowanie i promować rozwój objawowego cytomegalowirusowego zapalenia płuc. W pracy przedstawiono dwa przypadki PCP, które były pierwszym objawem zakażenia HIV. W obu udowodniono również zakażenie CMV.

Słowa kluczowe: pneumocystozowe zapalenie płuc, infekcje oportunistyczne, koinfekcja PCP/CMV

Pneumonol. Alergol. Pol. 2014; 82: 458-466

\section{Wstęp}

Według danych Światowej Organizacji Zdrowia pod koniec 2012 roku zakażenie HIV (human immunodeficiency virus) dotyczyło 35,3 miliona osób na świecie [1]. Skutkuje ono nieprawidłowym funkcjonowaniem i niedoborami ze strony układu immunologicznego i w konsekwencji prowadzi do zespołu nabytego niedoboru odporności (AIDS, acquired immunodeficiency syndrome). Główną grupą komórek zaangażowanych w ten proces są limfocyty T CD4+. W przewlekłej fazie infekcji dochodzi zarówno do ich nieprawidłowego funkcjonowania, jak i obniżenia ogólnej ich liczby. Występuje również upośledzenie funkcji limfocytów B, ich nieprawidłowa poliklonalna aktywacja z hipergammaglobulinemią, co doprowadza do zaburzeń produkcji swoistych przeciwciał podczas kontaktu z antygenem [2].

Opisane zmiany zachodzą rówież w obrębie układu oddechowego, przede wszystkim w przestrzeni pęcherzyków płucnych i śródmiąższu [2]. Zmiany te są jednak inne niż w obrębie innych błon śluzowych (na przykład w ścianie jelita). Profil komórek z badania popłuczyn oskrzelowo -pęcherzykowych (BALF, bronchoalveolar lavage fluid) u osób zakażonych HIV wykazuje zwiększony odsetek limfocytów T CD4+ oraz większą liczbę komórek T CD8+ linii różnicującej się specyficznie dla wirusa HIV. Wydaje się, że konsekwencją tego zjawiska jest mniej wyrażona destrukcja komórek układu odpornościowego w obrębie płuc w początkowych fazach zakażenia HIV [3]. Dochodzi do przetrwałego wewnątrzkomórkowego zakażenia kilku linii komórek układu odpornościowego w obrębie przestrzeni pęcherzykowej: limfocytów T CD8+, makrofagów i fibroblastów oraz nadmiernego wytwarzania interferonu-gamma. Prowadzi to, z jednej strony, do wtórnej aktywacji układu odpornościowego, z drugiej strony do nieprawidłowego działania komórek tego układu, upośledzenia rozpoznawania i prezentacji antygenów przez makrofagi oraz nieprawidłowych mechanizmów odpowiedzi komórkowej [2].

Schorzenia układu oddechowego związane z zakażeniem HIV tworzą spektrum chorób infek- cyjnych i nieinfekcyjnych (tab. 1). Wśród chorób infekcyjnych należy wymienić bakteryjne, grzybicze i wirusowe zakażenia układu oddechowego, zakażenia prątkami gruźlicy, mykobakteriozy, choroby pasożytnicze. Chorobom nieinfekcyjnym układu oddechowego, których ryzyko wystąpienia jest u osób zakażonych HIV kilkukrotnie wyższe niż u osób zdrowych, poświęca się coraz więcej uwagi, a są to między innymi przewlekła obturacyjna choroba płuc (POChP), śródmiąższowe zapalenia płuc prowadzące do włóknienia oraz tętnicze nadciśnienie płucne i nowotwory złośliwe [2].

Pneumocystis jiroveci to patogen oportunistyczny zaliczany do grzybów, którego głównym

Tabela 1. Schorzenia układu oddechowego u osób żyjących z HIV; za [1]

Table 1. Spectrum of respiratory system diseases in people living with HIV; based on [1]

\begin{tabular}{ll}
\hline Zakażenia bakteryjne & $\begin{array}{l}\text { Streptococcus pneumoniae } \\
\text { Haemophilus spp. } \\
\text { Staphylococcus aureus } \\
\text { Pseudomonas aeruginosa } \\
\text { Inne bakterie }\end{array}$ \\
& Mycobacterium tuberculosis \\
Zakażenia i choroby & M. avium complex \\
prątkowe & M. kansasii \\
& Pneumocystis jiroveci \\
Zakażenia grzybicze & Cryptococcus neoformans \\
& Histoplasma capsulatum \\
& Coccidioides immitis \\
& Aspergillus spp. \\
& Blastomyces sp. \\
& Penicillium narneffei \\
& Cytomegalowirus \\
& Inne wirusy \\
Choroby wywołane przez & Toxoplasma gondii \\
wirusy & Mięsak Kaposiego \\
Inwazje pasożytnicze & Chłoniaki nieziarnicze (NHL) \\
Choroby nowotworowe & Rak płuca \\
& Przewlekła obturacyjna choroba płuc \\
& Astma \\
Inne choroby nieinfek- & Limfocytarne śródmiąższowe \\
cyjne & zapalenia płuc \\
& Sętnicze nadciśnienie płucne \\
& Zarkoidoza (?) \\
& \\
&
\end{tabular}


rezerwuarem jest człowiek. Do przejściowej kolonizacji, przede wszystkim górnych dróg oddechowych, dochodzi najczęściej we wczesnym dzieciństwie; można wtedy wykryć swoiste przeciwciała we krwi [4]. Do powtórnej kolonizacji może dochodzić w różnych chorobach jak POChP czy zakażeniu HIV, opisuje się je również na przykład wśród kobiet ciężarnych [5]. Objawowa infekcja tym patogenem znana jako pneumocystoza płuc (PCP, Pneumocystis pneumonia) została w 1981 roku opisana u 15 mężczyzn mających stosunki seksualne z mężczyznami, dotychczas zdrowych, poprzedzało to globalną epidemię HIV [4]. Obecnie do kręgu osób potencjalnie, choć bardzo rzadko, narażonych na PCP, niezakażonych HIV, należą biorcy organów, chorzy z upośledzoną odpornością w przebiegu różnych chorób, w tym między innymi w toczniu rumieniowatym układowym czy ziarniniakowatości z zapaleniem naczyń (ziarniniakowatości Wegenera) [6].

\section{Przypadek 1}

Mężczyzna 42-letni, dotychczas zdrowy, został przyjęty do Instytutu Gruźlicy i Chorób Płuc z powodu przewlekającego się obustronnego zapalenia płuc bez poprawy klinicznej i radiologicznej mimo stosowanego leczenia. Chory skarżył się na uczucie osłabienia, stany podgorączkowe i kaszel z odkrztuszaniem ropnej plwociny. Pacjent negował nikotynizm, i kontakt z gruźlicą. Był kawalerem, mieszkającym w mieście, pracował fizycznie.

Z powodu nasilenia objawów (gorączka do $38,5 \mathrm{C}^{\circ}$ oraz duszność), wykonano badanie RTG klatki piersiowej. W obrazie uwidoczniono pasmowate zagęszczenia w dolnych partiach obu płuc, bardziej nasilone po stronie prawej. W leczeniu zastosowano kolejno: klarytromycynę, amoksycylinę z kwasem klawulanowym oraz ponownie klarytromycynę, nie uzyskując poprawy klinicznej. W wykonanym powtórnym radiogramie klatki piersiowej, uwidoczniono progresję zmian radiologicznych. Przy przyjęciu do szpitala pacjent był w stanie ogólnym średnim, z dusznością, tachypnoe - 50 oddechów/minutę, sinicą obwodową. Śluzówki jamy ustnej pokryte były licznymi pleśniawkami. Stwierdzano osłabienie szmeru pęcherzykowego po stronie prawej, u podstawy obu płuc liczne trzeszczenia. W badaniach laboratoryjnych RBC $3720 \mathrm{G} / \mathrm{L}$, HGB $11 \mathrm{~g} / \mathrm{dL}$, WBC 3,72 G/L w tym limfocyty 1,3 G/L, białko C-reaktywne (CRP, C-reactive protein) $21 \mathrm{mg} / \mathrm{L}$, prokalcytonina ujemna, D-dimer $2939 \mathrm{mcg} / \mathrm{L}$, w gazometrii hipoksemia z zasadowicą oddechową: $\mathrm{pO}_{2} 52,6 \mathrm{~mm} \mathrm{Hg}$, $\mathrm{pCO}_{2} 28,3 \mathrm{~mm} \mathrm{Hg}, \mathrm{pH} 7,52$.

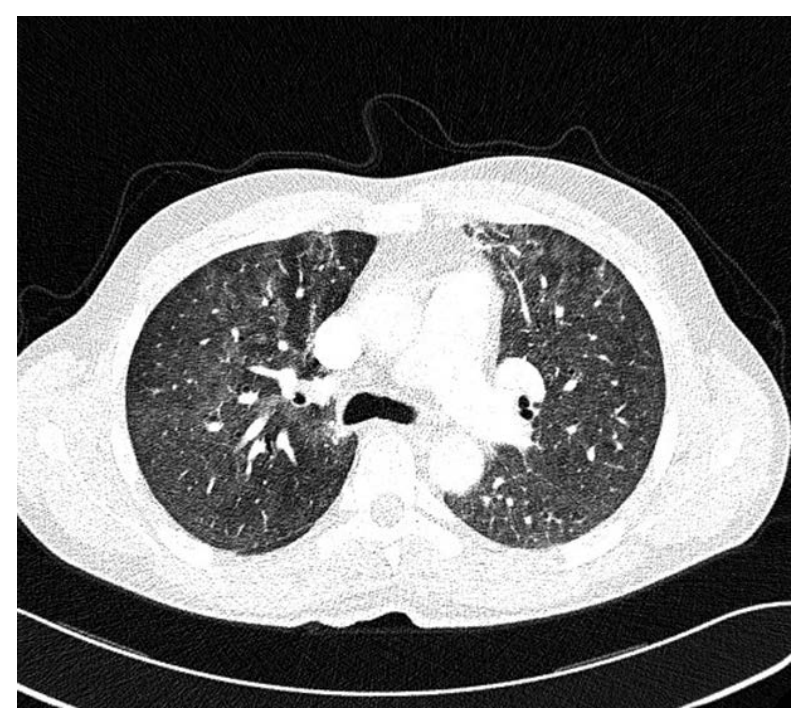

Rycina 1. Tomografia komputerowa wysokiej rozdzielczości płuc. Rozlane obszary matowej szyby zaoszczędzające wąski obszar podopłucnowy

Figure 1. Lung high-resolution computed tomography. Diffuse ground glass opacities sparing subpleural parts of lung parenchyma

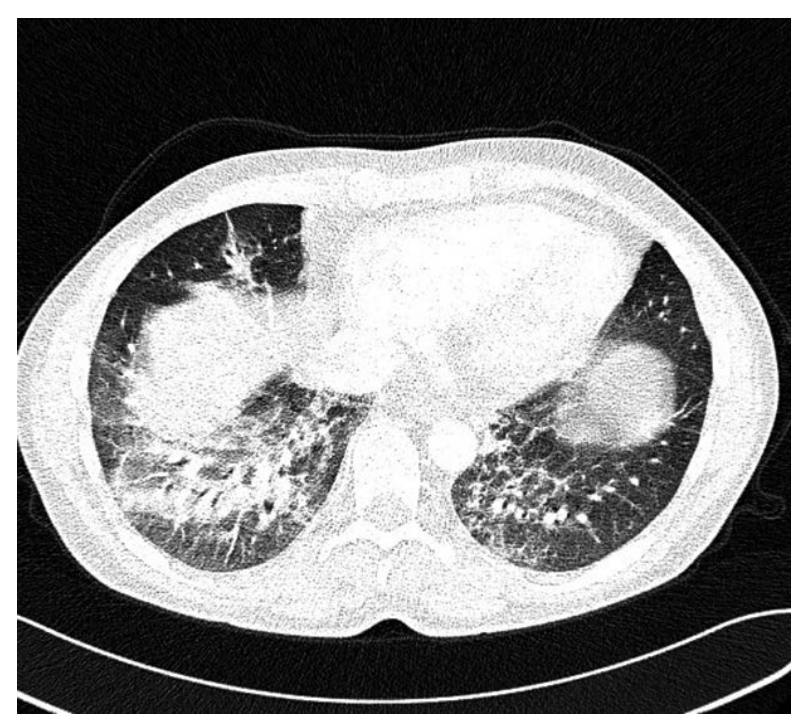

Rycina 2. Tomografia komputerowa wysokiej rozdzielczości płuc. Na poziomie płatów dolnych rozlane ogniska matowej szyby zlewają się w zagęszczenia miąższowe $z$ drożnym bronchogramem, z komponentem pogrubienia przegród międzyzrazikowych

Figure 2. Lung high-resolution computed tomography. Cross section at the level of inferior lobes: diffuse ground glass opacities, with interstitial consolidations and air bronchogram; thickening of interlobular septa

Na podstawie tomografii komputerowej klatki piersiowej w opcji naczyniowej wykluczono zatorowość płucną. Uwidoczniono natomiast obszary o typie „matowej szyby” oraz skonsolidowane zagęszczenia zapalne $\mathrm{w}$ dolnych płatach bardziej nasilone po stronie prawej, z widocznym 


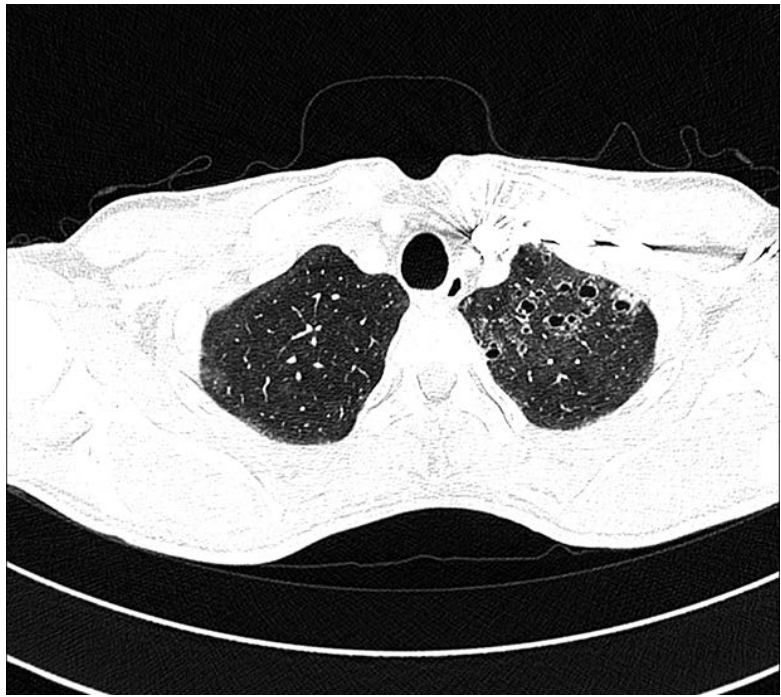

Rycina 3. Tomografia komputerowa wysokiej rozdzielczości płuc. Rozlane obszary matowej szyby; w szczycie lewego płuca mnogie drobne torbielki

Figure 3. Lung high-resolution computed tomography. Diffuse ground glass opacities; multiple small thin-walled cysts in the left apex

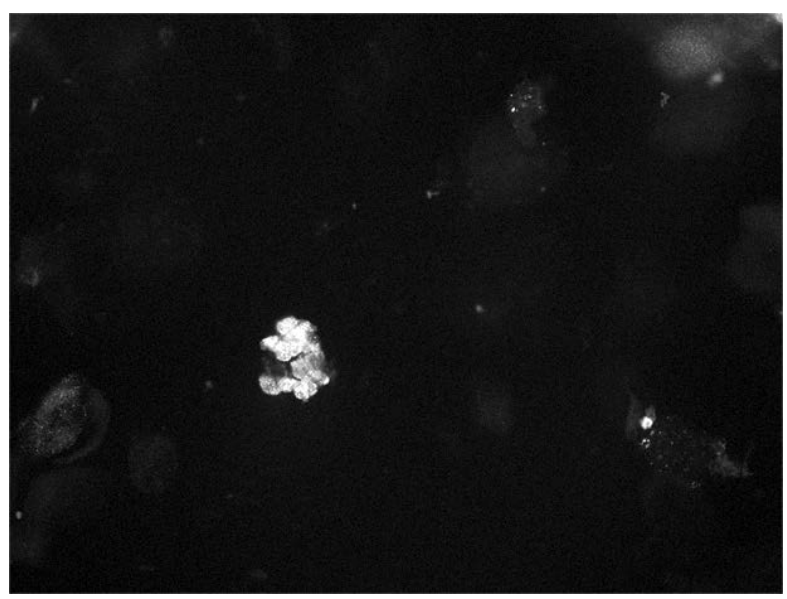

Rycina 4. Obraz z mikroskopu fluorescencyjnego (pow. $\times 400$ ). Dodatnia reakcja immunofluorescencji pośredniej na antygeny P.jiroveci, skupisko 0ocyst w plwocinie

Figure 4. Fluoroscopic microscope view (magn. $\times 400$ ). Positive indirect fluoroscopic reaction with P.jiroveci antygenes; sputum oocists

powietrznym bronchogramem (ryc. 1, 2). W leczeniu zastosowano: tlenoterapię $2 \mathrm{l} / \mathrm{min}$ oraz antybiotykoterapię empiryczną ceftazydymem i klarytromycyną. Badania w kierunku zakażenia drobnoustrojami atypowymi wypadły ujemnie. $\mathrm{Na}$ podstawie analizy wykonanych badań i przebiegu choroby wysunięto podejrzenie zapalenia płuc o etiologii Pneumocystis jiroveci. Zastosowano empiryczne leczenie trimetoprim/sulfametoksazol w dożylnej dawce $4 \times 1920 \mathrm{mg}$. W trakcie leczenia uzyskano dodatni wynik badania plwociny metodą immunofluorescencji pośredniej w kierunku

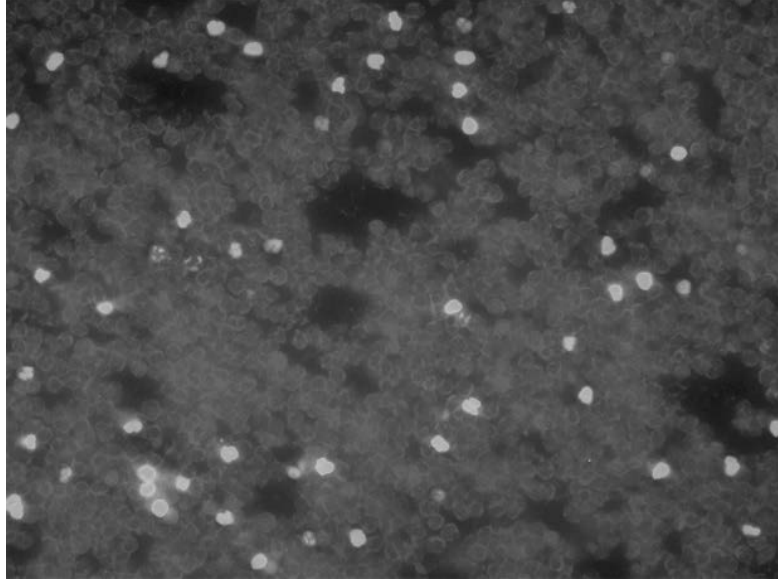

Rycina 5. Obraz z mikroskopu fluorescencyjnego (pow. $\times 400$ ). Dodatnia reakcja immunofluorescencji pośredniej na antygen pp65 CMV, liczne zainfekowane leukocyty krwi obwodowej

Figure 5. Fluoroscopic microscope view (magn. $\times 400$ ). Positive indirect fluoroscopic reaction with pp65 CMV antigene; numerous infected leucocytes among blood cells

obecności oocyst $P$. jiroveci (ryc. 4) oraz dodatni wynik badania immunofluorescencji pośredniej w kierunku obecności antygenu pp65 cytomegalowirusa (CMV) na powierzchni leukocytów krwi obwodowej (ryc. 5); podano gancyklowir $2 \times 350 \mathrm{mg}$ dożylnie. Początkowe antybiotyki odstawiono.

Ostatecznie w opisywanym przypadku uzyskano dodatni wynik badania serologicznego w kierunku zakażenia HIV (metodą ELISA), który potwierdzono metodą Western blot. W badaniu cytometrii przepływowej stwierdzono obniżone stężenie limfocytów CD4+ do 0.029 G/L, świadczące o znacznym upośledzeniu odporności pacjenta. Obniżone były również wartości bezwzględne limfocytów B CD3+, CD19+ oraz komórek NK CD16+, CD56+.

$\mathrm{W}$ trakcie leczenia obserwowano narastającą pancytopenię: WBC 1.9 G/L, RBC 3110 G/L, HGB $8.9 \mathrm{~g} / \mathrm{dL}$, PLT $127 \mathrm{M} / \mathrm{L}$.

Z powodu trombocytopenii PLT 60M/L w 20. dobie zakończono leczenie gancyklowirem. Po 3 tygodniach terapii uzyskano stopniową poprawę stanu klinicznego oraz częściową regresję zmian radiologicznych $w$ płucach. Nie ustalono czasu ani drogi zakażenia HIV.

W 21. dobie leczenia preparat dożylny tripetoprimu/sulfametoksazolu zastąpiono formą doustną $(1 \times 960 \mathrm{mg} / 24 \mathrm{~h})$, tym samym rozpoczynając profilaktykę wtórną PCP, i wypisano pacjenta ze szpitala z zaleceniem kontynuacji leczenia w warunkach ambulatoryjnych $\mathrm{z}$ intencją rozpoczęcia tamże leczenia antyretrowirusowego (ART, antiretroviral therapy). 


\section{Przypadek 2}

Mężczyzna 27-letni, został skierowany do Izby Przyjęć Instytutu Gruźlicy i Chorób Płuc w celu diagnostyki utrzymujących się od około miesiąca zmian zapalnych $\mathrm{w}$ obu płucach, niereagujących na leczenie ambulatoryjne. $\mathrm{W}$ wywiadzie chorobowym: ospa wietrzna powikłana małopłytkowością przed rokiem, a następnie półpasiec. Od ponad roku występowały również nawracające zmiany skórne o charakterze ropnym lub grzybiczym. Chory negował nikotynizm i kontakt z gruźlicą. Żył w związku homoseksualnym.

Obecna choroba rozpoczęła się gorączką do $38^{\circ} \mathrm{C}$ i dusznością wysiłkową z towarzyszącym znacznym osłabieniem. Okresowo występował kaszel z miernym odkrztuszaniem śluzowo-ropnej plwociny. Stosowano empirycznie klarytromycynę przez 3 tygodnie, nie uzyskując poprawy klinicznej. W wykonanym badaniu RTG klatki piersiowej opisywano obustronne zmiany miąższowe w dolnych polach płuc. W badaniu tomografii komputerowej klatki piersiowej uwidoczniono rozlane obszary typu „matowej szyby”, ponadto w szczycie lewego płuca mnogie, drobne torbielki (ryc. 3), a w polach dolnych obu płuc linijne struktury wskazujące na współistnienie komponentu śródmiąższowego. W badaniu przedmiotowym przy przyjęciu stwierdzono niewielką duszność, bez sinicy. Zwracała uwagę kacheksja - indeks masy ciała (BMI, body mass index) wynosił $16 \mathrm{~kg} / \mathrm{m}^{2}$. Na skórze pleców zwracała uwagę duża zmiana o charakterze złuszczającego się wykwitu rumieniowego, poza tym widoczne były mniejsze łuszczące się zmiany rumieniowe na twarzy. W badaniu klatki piersiowej stwierdzono stłumienie odgłosu opukowego u podstawy prawego płuca, nieznacznie ściszony szmer pęcherzykowy w polu dolnym płuca prawego. W badaniach laboratoryjnych: RBC $4350 \mathrm{G} / \mathrm{L}$, HGB 11,5 g/dL, WBC 5,01 G/L z prawidłowym rozmazem,CRP 5,8 mg/L,LDH942 U/L,D-dimer 1835 mcg/L, w gazometrii arterializowanej krwi kapilarnej stwierdzono hipoksemiczną niewydolność oddychania: $\mathrm{pO}_{2} 53 \mathrm{~mm} \mathrm{Hg}, \mathrm{pCO}_{2} 33,4 \mathrm{~mm} \mathrm{Hg}$, pH 7,48.

Ze względu na podejrzenie pneumocystozy, rozpoczęto tlenoterapię i empiryczne leczenie trimetoprimem $\mathrm{z}$ sulfametoksazolem $\mathrm{w}$ dawce $4 \times 1440$ mg dożylnie.

Ponadto, stwierdzono wysokie miano przeciwciał anty-CMV w klasie IgG i niskie w klasie IgM. Wykazano również obecność antygenu pp65 CMV w leukocytach krwi obwodowej. Do leczenia dołączono gancyklowir w dawce $2 \times 250 \mathrm{mg}$ do- żylnie. W wyniku stosowanego leczenia w trakcie 7 dni obserwacji uzyskano nieznaczną poprawę kliniczną.

W trakcie hospitalizacji uzyskano dodatni wynik badania serologicznego w kierunku zakażenia HIV (metodą ELISA), potwierdzając zakażenie metodą Western blot.

$\mathrm{W}$ badaniu cytometrii przepływowej stwierdzono niskie stężenie limfocytów CD4 $+-0,025$ G/L i limfocytów B CD19+- -0,038 G/L.

W badaniu cytologicznym plwociny metodą pośredniej immunofluorescencji nie stwierdzono cyst $P$. jiroveci. Na bronchofiberoskopię pacjent nie wyraził zgody.

Pomimo braku subiektywnych skarg, podczas rutynowej konsultacji okulistycznej, wysunięto podejrzenie zapalenia siatkówki o etiologii CMV. Pacjent został przeniesiony do Szpitala Zakaźnego w Warszawie w celu dalszego leczenia.

\section{Omówienie}

Przed erą HIV/AIDS pneumocystoza była chorobą bardzo rzadką, opisywaną wśród dzieci z pierwotnymi niedoborami odporności oraz u osób z chorobami nowotworowymi, głównie białaczkami [7]. W latach 1990-1993 PCP było najczęstszą chorobą poprzedzającą rozpoznanie zakażenia HIV w USA [4]. Zgodnie z raportem World Health Organization z 2008 roku, w Europie ponad 16\% rozpoznań AIDS ustalono w związku z zachorowaniem na pneumocystoze [4]. W Wielkiej Brytanii PCP było najczęstszą chorobą wskaźnikową notowaną w latach 2010-2012 i powodem $33 \%$ rozpoznań AIDS [8]. Połączone badania 15 kohort europejskich i północnoamerykańskich wykazało, że pneumocystoza wciąż jest drugą po grzybicy przełyku, chorobą wskaźnikową AIDS [9].

Pneumocystoza stanowi poważny problem $\mathrm{w}$ krajach rozwijających się. Śmiertelność z powodu PCP w populacji chorych zakażonych HIV w Ugandzie sięga 75\%, gdy w tym samym czasie śmiertelność z powodu gruźlicy płuc wynosi $31 \%$, a w kryptokokowym zapaleniu płuc 10\% [10]. Śmiertelność $\mathrm{w}$ przebiegu PCP $\mathrm{w}$ krajach rozwiniętych wynosi obecnie 9-11\% [7].

Opisani chorzy są przykładem późnego rozpoznania zakażenia HIV (late presenters) w związku z wystąpieniem pneumocystozy. Pacjenci nie byli świadomi zakażenia HIV. W krajach rozwiniętych 43\% wszystkich przypadków PCP występowało u osób nieświadomych zakażenia HIV [7].

Analiza dostępnych badań pokazuje, że średnie stężenie limfocytów T CD4+ pacjentów 
Tabela 2. Obraz kliniczny pneumocystozowego zapalenia płuc

Table 2. Clinical manifestation of pneumocystis pneumonia

\footnotetext{
Wywiad:

— powolny i skryty początek, stopniowo nasilająca się duszność

- gorączka

- suchy kaszel

— trudności w oddychaniu, we wzięciu głębokiego wdechu, niespowodowane bólem w klatce piersiowej

Badanie przedmiotowe:

— często bez wyraźnych odchyleń w spoczynku;

- tachypnoe

— tachykardia

— rozsiane trzeszczenia podczas głębokiego oddychania

— inne cechy sugerujące niedobór odporności (leukoplakia języka, zmiany skórne)

Badania laboratoryjne:

— różnego stopnia hipoksemia (najbardziej charakterystyczna!)

— LDH często powyżej $500 \mathrm{mg} / \mathrm{dL}$;

— obniżenie zdolności dyfuzyjnej dla tlenka węgla (DLCO)

Badania obrazowe (RTG i HRCT):

— obustronne odwnękowe obszary matowej szyby, przypominające pęcherzykowy obrzęk płuc*

- wspótistnienie cienkościennych torbielek (pneumatocele) ${ }^{* *}$

— rzadko wysięk opłucnowy, zagęszczenia miąższowe z pogrubieniem przegród międzyzrazikowych, odczyn węzłowy w śródpiersiu

— odma opłucnowa (każdorazowo odma u chorego żyjącego z HIV powinna nasuwać podejrzenie PCP)

*patrz ryc. $1,2,{ }^{* *}$ patrz ryc. $3 ; \mathrm{DLCO}$ - carbon monoxide diffusion in the lung; objaśnienia pozostałych skrótów w tekście
}

z rozpoznaną pneumocystozą wynosi 13-30 komórek/mcL [7]. Szacuje się, że u około 5\% chorych z liczbą T CD4+ powyżej 200 komórek/ mcL rozwinie się objawowa pneumocystoza. Jedynym dodatkowym potwierdzonym czynnikiem ryzyka rozwoju PCP jest płeć męska [7]. Zgodnie z przedstawionymi faktami, przypadki prezentowane w obecnej pracy dotyczą mężczyzn, z liczbą limfocytów T CD4+ 29 i 25 komórek/mcL.

Najczęstsze objawy podmiotowe i przedmiotowe oraz obraz radiologiczny PCP zebrano w tabeli 2. Zarówno wywiad chorobowy, jak i wyniki badań radiologicznych $\mathrm{w}$ obu prezentowanych przypadkach wydają się zgodne z przedstawionymi w piśmiennictwie. W literaturze podkreśla się dłuższy i bardziej skryty rozwój objawów u zakażonych HIV niż u pacjentów w stanach immunosupresji o innej etiologii [4, 7]. U jednego z pacjentów stwierdzono uważaną za charakterystyczną dla PCP podwyższoną aktywność LDH (lactate dehydrogenase) [7]. W obu przypadkach obserwowano nieznacznie podwyższone stężenie markerów stanu zapalnego (leukocytoza i CRP) oraz wysokie stężenie D-dimeru. Przebieg klinicz- ny jednego z opisywanych przypadków nasuwał podejrzenie zatorowości płucnej, która została wykluczona badaniem tomograficznym klatki piersiowej w opcji naczyniowej.

Brakuje jednoznacznych wytycznych postępowania przy podejrzeniu PCP. Niektóre ośrodki dążą do ustalenia rozpoznania, głównie metodami biologii molekularnej, inne z kolei stosują terapię empiryczną, której rozpoczęcie wymaga wykluczenia innych możliwych zakażeń występujących w chorych w immunosupresji, w tym gruźlicy [7]. W prezentowanych przypadkach, wyniki posiewów plwociny w kierunku gruźlicy były negatywne.

Główną metodą diagnostyczną u chorych podejrzanych o PCP jest badanie materiału z dolnych dróg oddechowych i stwierdzenie w obrazie mikroskopii fluorescencyjnej obecności charakterystycznych cyst bądź form troficznych (ryc. 4). „Złotym standardem” w diagnostyce PCP jest immunofluorescencja materiału uzyskanego w trakcie bronchofiberoskopii z wykonaniem BAL, jej czułość diagnostyczna sięga 98\% [4]. Wydaje się, że dostępność tej metody ograniczona jest głównie ciężkim stanem klinicznym pacjentów, będącym przeciwwskazaniem do wykonania BAL, w takich przypadkach polecić można diagnostykę indukowanej plwociny. Innymi używanymi metodami diagnostycznymi są: sondy genetyczne z użyciem metody PCR z materiału uzyskanego z dróg oddechowych - o czułości 88 i swoistości 90\%. Zasadniczą wadą metody jest brak możliwości zróżnicowania kolonizacji górnych dróg oddechowych bez aktywnych form $P$. jiroveci od objawowej pneumocystozy [4]. Trwają badania nad biochemicznymi markerami pneumocystozy. Potencjalnie użytecznym biomarkerem wydaje się S-adenozylometionina, której aktywność u osób zakażonych $P$. jiroveci jest niższa niż u osób zdrowych oraz z infekcjami układu oddechowego o innej etiologii [4].

U opisywanych pacjentów, w pierwszym przypadku zakażenie $P$. jiroveci potwierdzono badaniem plwociny w mikroskopie fluorescencyjnym, w którym uwidoczniono cysty. W drugim przypadku, badanie plwociny było ujemne, zaplanowane badanie bronchofiberoskopowe nie odbyło się z powodu braku zgody pacjenta, a rozpoznanie postawiono na podstawie obrazu klinicznego i wyników badań dodatkowych.

Lekiem $\mathrm{z}$ wyboru $\mathrm{w}$ PCP jest trimetoprim (TMP) z sulfametoksazolem (SMX). Standardowe dawkowanie obejmuje $15-20 \mathrm{mg} / \mathrm{kg} \mathrm{mc}$. TMP oraz 75-100 mg/kg mc. SMX w 2-4 dawkach podzielonych, dożylnie, przez 21 dni [4, 5, 7]. Po 7-10 
dniach podawania leku dożylnie, w przypadku poprawy klinicznej, można rozważyć podaż doustną. Niepowodzeniem terapii należy nazwać brak poprawy lub pogorszenie czynności układu oddechowego udokumentowane pomiarami gazometrii krwi tętniczej, po 4-8 dniach leczenia PCP. Wymaga to każdorazowo ponownej diagnostyki różnicowej i rozważenia alternatywnych metod leczenia [7]. W obu prezentowanych przypadkach zastosowano standardową terapię TMP/SMX. Poprawa kliniczna w pierwszym przypadku nastąpiła między 7. a 10. dniem leczenia, w drugim między dniem 5. a 7.

U pacjentów z AIDS obserwuje się wysoki odsetek (20-85\%) działań niepożądanych w terapii TMP/SMX. Do najczęstszych należą wysypka, gorączka, leukopenia, trombocytopenia, toksyczne zapalenie wątroby. Wydaje się, że obserwowana w 2. i 3. tygodniu leczenia supresja szpiku u pierwszego pacjenta mogła być związana z toksycznym działaniem TMP/SMX, terapii jednak nie przerwano, za substancję szkodliwą przyjęto podawany równocześnie gancyklowir.

W terapii alternatywnej PCP stosowana jest pentamidyna (podawana dożylnie), klindamycyna z primakwiną, dapson i atowakwon $[4,5,7]$. Stosowanie glikokortykosteroidów (GKS) w przebiegu PCP zalecane jest u pacjentów ze średnim i ciężkim przebiegiem choroby, którego kryterium jest hipoksemia krwi tętniczej $\left(\mathrm{pO}_{2}\right.$ poniżej $70 \mathrm{~mm} \mathrm{Hg}$ ) i/lub gradient pęcherzykowo-tętniczy tlenu powyżej $35 \mathrm{~mm} \mathrm{Hg}$. Leczenie przy użyciu GKS powinno być rozpoczęte razem z leczeniem przeciwdrobnoustrojowym, nie później niż 72 godziny po rozpoczęciu chemoterapii [4]. Zalecany jest prednizon w dawce początkowej $2 \times 40 \mathrm{mg}$ przez 1-5 dni, ze stopniową redukcją dawki, o $40 \mathrm{mg}$ w 6.-10. dniu i $20 \mathrm{mg} \mathrm{w}$ 11.-21. dniu terapii. W przypadku konieczności podania dożylnego leku można zastosować metyloprednizolon (w dawce $75 \%$ prednisonu) [5].

Mimo spełnienia kryteriów, opisywani pacjenci nie otrzymywali systemowego leczenia GKS. Powodem takiej decyzji był względnie dobry stan ogólny chorych oraz ryzyko związane z możliwością progresji zakażenia CMV.

Kwestią dyskusyjną jest czas rozpoczęcia ART u chorych zakażonych HIV, u których wystąpiła pneumocystoza. Przeważa pogląd wczesnego rozpoczynania terapii ART, najpóźniej 2 tygodnie od rozpoznania pneumocystozy [5]. Z powodu braku doświadczenia nie podawano leków antyretrowirusowych u pacjentów w przypadkach opisanych powyżej, obaj zostali skierowani do ośrodka referencyjnego chorób zakaźnych z tą intencją. U chorych na PCP leczonych ART może wystąpić $\mathrm{w}$ ciągu pierwszych tygodni leczenia zespół rekonstrukcji immunologicznej (IRIS, immune reconstitution inflammatory syndrome) pod postacią nasilenia objawów PCP i zmian radiologicznych w płucach z towarzyszącą hipoksemią. Objawy te wynikają ze zmniejszenia stanu immunosupresji, przebieg zespołu IRIS jest zwykle łagodny, może on jednak wydłużyć okres rekonwalescencji [7]. Wdrażanie ART powinno pozostawać pod kontrolą lekarzy mających doświadczenie w leczeniu antyretrowirusowym.

Wprowadzenie wysokoaktywnej terapii antyretrowirusowej (HAART, highly active antiretroviral therapy) oraz profilaktyki zakażeń oportunistycznych u zakażonych HIV spowodowało wydłużenie średniego czasu przeżycia chorych zakażonych HIV i przekształcenie śmiertelnej choroby w zakażenie przewlekłe [5, 11].

$\mathrm{W}$ profilaktyce pierwotnej PCP zalecany jest TMP/SMX w pojedynczej zwykłej dawce dobowej $-80 \mathrm{mg} / 400 \mathrm{mg}$ lub dawce zwiększonej - 160 $\mathrm{mg} / 800 \mathrm{mg}$. Udowodniono również skuteczność podawania trzech dawek na tydzień (po $960 \mathrm{mg}$ na dawkę) - jednak zalecenie to ma mniejszą siłę w rekomendacjach. Wskazaniem do rozpoczęcia pierwotnej profilaktyki PCP jest liczba limfocytów T CD4+ poniżej 200 kom./mcL bądź występowanie kandydozy jamy ustnej i gardła. Wskazaniami o mniejszej sile zaleceń są: procent T CD4 względem ogółu $-<14 \%$, przebyta jakakolwiek choroba wskaźnikowa AIDS oraz u pacjentów z liczbą komórek T CD4 200-250 gdy niemożliwe jest monitorowanie stężenia limfocytów T CD4 co najmniej co 3 miesiące [5]. Jeżeli z powodu działań niepożądanych terapia jest przerywana, należy dążyć do jej ponownego rozpoczęcia po ich ustąpieniu. W przypadku zwiększenia się poziomu T CD4+ powyżej $200 \mathrm{kom} . / \mathrm{mcL}$ przez ponad 3 miesiące obserwacji profilaktykę pierwotną można odstawić. Wskazaniem do profilaktyki wtórnej jest przebyta pneumocystoza. Zasady stosowania profilaktyki wtórnej opierają się na tych samych wartościach komórek T CD4+ co w przypadku profilaktyki pierwotnej. U chorych, którzy przebyli PCP, należy jednak rozważyć bezterminową profilaktykę wtórną, nawet gdy liczba komórek T CD4 jest wyższa niż 200/mcL. Profilaktyka pierwotna i wtórna powinna dotyczyć również dzieci oraz kobiet ciężarnych $[5,11]$. U jednego z omawianych chorych po zakończeniu 3-tygodniowego leczenia PCP, kontynuowano podawanie TMP/ SMX w dawkach profilaktycznych.

$\mathrm{U}$ obu z omawianych chorych rozpoznano zakażenie CMV. Przebyte zakażenie CMV, często 
ulega reaktywacji, szczególnie w stanie immunosupresji, jest więc traktowane u chorych zakażonych wirusem HIV jako nosicielstwo. Zakażenie CMV jest niekorzystnym czynnikiem rokowniczym i zwiększa śmiertelność w grupie chorych zakażonych HIV [12].

Częstość latentnego nosicielstwa CMV w populacji ogólnej (występowanie przeciwciał w surowicy) szacowana jest na ponad $40 \%$, a wśród chorych zakażonych HIV jest wyższa [5, 13]. Wiąże się to prawdopodobnie ze wspólnymi drogami szerzenia się zakażeń - przez bezpośredni kontakt z płynami ustrojowymi, a w przypadku CMV również poprzez ślinę [5]. Objawowe zakażenie CMV u pacjentów zakażonych HIV to zapalenie siatkówki (najczęściej), zapalenie jelit, zapalenie przełyku, zapalenie płuc (niezmiernie rzadko), stany neurologiczne związane z CMV takie jak zapalenie mózgu i/lub rdzenia, demencja, zespoły korzeniowe [13].

Cytomegalowirus jest patogenem często izolowanym $\mathrm{z}$ dróg oddechowych pacjentów z AIDS, ale jego chorobotwórczość w stosunku do układu oddechowego jest wciąż dyskutowana [13]. Nadal nie zdefiniowano jasno kryteriów rozpoznawania zapalenia płuc w przebiegu CMV, mimo metod cytologicznego rozpoznawania komórek zakażonych CMV oraz metod hodowli wirusowej [12]. Uważa się, że diagnoza cytomegalowirusowego zapalenia płuc powinna być postawiona po jednoznacznej identyfikacji CMV jako patogenu ze śródmiąższu płucnego (z bioptatu płuca), ewentualnie potwierdzenie zakażenia komórek CMV w BAL. Każdorazowo należy wykluczyć wszystkie inne patogeny mogące powodować objawy chorobowe [5]. Metody diagnostyczne o dużo mniejszej wartości przy rozpoznawaniu zajęcia narządowego przez CMV to stwierdzenie obecności antygenu pp65 w komórkach krwi obwodowej (ryc. 5) oraz wykrywanie przeciwciał. Metody te były stosowane w obu omawianych przypadkach. Należy więc zaznaczyć, że uzyskane wyniki należy interpretować z dużą ostrożnością.

Uważa się, że w płucach CMV jest patogenem często współistniejącym z $P$. jiroveci. Podejrzewa się (na podstawie danych od chorych po przeszczepieniach), że zakażenie CMV promuje przejście kolonizacji P. jiroveci w objawowe PCP [14]. Leczenie za pomocą gancyklowiru potwierdzonego cytomegalowirusowego zapalenia płuc nie ma wystarczających podstaw w badaniach klinicznych [5].

Profilaktyka pierwotna CMV, ze względu na bardzo wysoki koszt, toksyczność oraz wysoki wskaźnik NNT (number-needed-to-treat to reduce disease), nigdy nie została zapisana w rekomendacjach jako bezwzględnie wskazana. Stosowany może być doustny preparat gancyklowiru, należy ją rozważać u osób z dodatnimi przeciwciałami anty-CMV oraz ze stężeniem limfocytów CD4+ poniżej $50 \mathrm{kom} . / \mathrm{mcL}$ [5]. Profilaktyka wtórna, która następuje po początkowym leczeniu indukcyjnym zapalenia siatkówki (bądź innego udowodnionego zajęcia narządu) opiera się na podawaniu doustnym gancyklowiru lub valgancyklowiru. Jej ewentualne przerwanie można rozważać u chorych ze stabilizacją objawów okulistycznych i trwałym (powyżej pół roku) zwiększeniem liczby komórek T CD4+ powyżej 100-150/mcL [5, 11].

W obu prezentowanych przypadkach mieliśmy do czynienia z chorymi ze współzakażeniem P.jiroveci/CMV. Prawdopodobnie wpływ wirusa na przebieg śródmiąższowego zapalenia płuc w obu przypadkach był niewielki. W pierwszym przypadku należałoby zrewidować wskazania do systemowego leczenia gancyklowirem. Prawdopodobnie decyzja ta została podjęta zbyt pochopnie. Faktem przemawiającym za zastosowaniem leczenia/profilaktyki chorób związanych z CMV była skrajnie mała liczba komórek T CD4+, a dożylna podaż gancyklowiru była przede wszystkim poparta klinicznymi doświadczeniami autorów. W drugim prezentowanym przypadku podawanie dożylne gancyklowiru było w pełni uzasadnione po uzyskaniu wyniku konsultacji okulistycznej (najczęstsza manifestacja narządowa objawowej choroby CMV). W obu przedstawionych przypadkach PCP należy spodziewać się gorszego rokowania i statystycznie wyższej śmiertelności długoterminowej. Niezastosowanie GKS systemowych w pełnym 21-dniowym cyklu mogło zdaniem autorów zmniejszyć ryzyko objawowego zapalenia płuc o etiologii CMV u tych chorych w przyszłości; brakuje jednak jednoznacznych dowodów popierających takie stanowisko [4, 5, 15].

Podsumowując, należy podkreślić, że mimo częstości występowania PCP oraz dużego rozpowszechnienia zakażenia CMV w populacji chorych zakażonych HIV, do dziś nie ma jednoznacznych wskazań dotyczących postępowania w przypadku współistnienia tych dwóch chorób, a stosowanie systemowych glikokortykosteroidów powinno być rozpatrywane indywidualnie z uwzględnieniem potencjalnych korzyści, które wynikają z ich zastosowania. Stosowanie gancyklowiru bez jednoznacznych dowodów choroby wywołanej przez CMV jest niewskazane. 


\section{Podziękowania}

Uprzejmie dziękujemy pani prof. dr hab. n. med. Joannie Chorostowskiej-Wyminko oraz pani dr n. med. Adrianie Roży z Zakładu Genetyki i Immunologii Klinicznej IGiChP za udostępnienie materiału fotograficznego z immunofluorescencji.

\section{Konflikt interesów}

Autorzy deklarują brak konfliktu interesów.

\section{Piśmiennictwo:}

1. World Health Organisation. WHO. HIV/AIDS. [2014 March 01] http://www.who.int/hiv/data/en/.

2. Crothers K., Thompson B.W., Burkhardt K. i wsp. HIV-associated lung infections and complications in the era of combination antiretroviral therapy. Proc. Am. Thorac. Soc. 2011; 8: 275 .

3. Brenchley J.M., Knox K.S., Asher A.I. i wsp. High frequencies of polyfunctional HIV-specific T cells are associated with preservation of mucosal CD4 T cells in bronchoalveolar lavage. Mucosal Immunol. 2008; 1: 49-58.

4. Huang L., Cattamanchi A., Davis J.L. i wsp. HIV-associated Pneumocystis pneumonia. Proc. Am. Thorac. Soc. 2011; 8: 294-300.

5. Centers for Disease Control and Prevention. Guidelines for Prevention and Treatment of Opportunistic Infections in HIV-Infected Adults and Adolescents. MMWR. 2009; 58(RR-4).
6. Calderón E.J., Gutiérrez-Rivero S., Durand-Joly I., Dei-Cas E Pneumocystis infection in humans: diagnosis and treatment. Expert Rev. Anti Infect. Ther. 2010; 8: 683-701.

7. Miller R.F., Huang L., Walzer P.D. Pneumocystis pneumonia associated with human immunodeficiency virus. Clin. Chest Med. 2013; 34: 229-241.

8. Aghaizu A., Brown A., Nardone A., Delpech V., Gill O. HIV in the United Kingdom 2013 Report: data to end 2012. Health Policy 2009; 9 3: 93-101.

9. Mocroft A., Sterne J.A., Egger M. Variable impact on mortality of AIDS-defining diagnosed during combination antiretroviral therapy: not all AIDS-defining condition are created equal. Aniretroviral Therapy Collaboration (ART-CC). Clin. Infect. Dis. 2009; 48: 1138-1151.

10. Kyeyune R., Den Boon S., Cattamanchi A. i wsp. Causes of early mortality in HIV-infected TB suspects in an East African referral hospital. J. Acquir. Immune. Defic. Syndr. 2010; 55: 446-450.

11. Masur H., Kaplan J.E., Holmes K.K. Guidelines for Preventing Opportunistic Infections among HIV-Infected Persons - 2002. Ann. Intern. Med. 2002; 137: 435-477.

12. Hayner C.E., Baughman R.P., Linnemann C.C., Dohn M.N. The relationship between cytomegalovirus retrieved by bronchoalveolar lavage and mortality in patients with HIV. Chest 1995; 107: 735-740.

13. De la Hoz R.E., Stephens G., Sherlock C. Diagnosis and treatment approaches of CMV infections in adult patients. J. Clin. Virol. 2002; 25: 1-12.

14. Pliquett R.U., Asbe-Vollkopf A., Hauser P.M. i wsp. A Pneumocystis jirovecii pneumonia outbreak in a single kidney-transplant center: role of cytomegalovirus co-infection. Eur. J. Clin. Microbiol. Infect. Dis. 2012; 31: 2429-2437.

15. Jensen A.B., Lundgren J., Benfield T., Nielsen T.L., Vestbo J. Does cytomegalovirus predict a poor prognosis in Pneumocystis carini pneumonia treated with corticosteroids? Chest. 1995; 108: 411-414. 